\title{
Impact of Adaptive Thermogenesis in Mice on the Treatment of Obesity
}

\author{
Marianela Bastías-Pérez ${ }^{1}$, Sebastián Zagmutt ${ }^{1}$, M Carmen Soler-Vázquez ${ }^{1}$, Dolors Serra ${ }^{1,2, * \mathbb{C} \text {, }}$ \\ Paula Mera 1,2,*(D) and Laura Herrero 1,2,*(D) \\ 1 Department of Biochemistry and Physiology, School of Pharmacy and Food Sciences, Institut de Biomedicina \\ de la Universitat de Barcelona (IBUB), Universitat de Barcelona, E-08028 Barcelona, Spain \\ 2 Centro de Investigación Biomédica en Red de Fisiopatología de la Obesidad y la Nutrición (CIBEROBN), \\ Instituto de Salud Carlos III, E-28029 Madrid, Spain \\ * Correspondence: dserra@ub.edu (D.S.); pmera@ub.edu (P.M.); lherrero@ub.edu (L.H.)
}

Received: 16 December 2019; Accepted: 27 January 2020; Published: 28 January 2020

\begin{abstract}
Obesity and associated metabolic diseases have become a priority area of study due to the exponential increase in their prevalence and the corresponding health and economic impact. In the last decade, brown adipose tissue has become an attractive target to treat obesity. However, environmental variables such as temperature and the dynamics of energy expenditure could influence brown adipose tissue activity. Currently, most metabolic studies are carried out at a room temperature of $21^{\circ} \mathrm{C}$, which is considered a thermoneutral zone for adult humans. However, in mice this chronic cold temperature triggers an increase in their adaptive thermogenesis. In this review, we aim to cover important aspects related to the adaptation of animals to room temperature, the influence of housing and temperature on the development of metabolic phenotypes in experimental mice and their translation to human physiology. Mice studies performed in chronic cold or thermoneutral conditions allow us to better understand underlying physiological mechanisms for successful, reproducible translation into humans in the fight against obesity and metabolic diseases.
\end{abstract}

Keywords: obesity; adaptive thermogenesis; brown adipose tissue; basal metabolic rate; thermoneutrality; chronic cold; ambient temperature and body temperature

\section{Introduction}

Endotherms, such as mammals, are organisms that use the heat released during cell metabolism to maintain a stable internal temperature [1]. This constant central temperature maintenance favors metabolic conditions so that enzymatic reactions can be carried out optimally, allowing endothermic organisms to be active and adapt to various environments through internal thermoregulation $[2,3]$.

Since a stable core temperature is essential for the survival of endotherms, endothermic animals do everything possible to defend their core temperature in colder environments (Figure 1). However, when central temperature defense is not possible, such as during food shortages or seasonal cold periods, many endotherms, including mice, leave homeothermy and engage in seasonal drowsiness or hibernation to conserve energy $[4,5]$.

The experimental mouse, Mus musculus, is one of the most commonly used model organisms for studies of metabolism, immunity and cardiovascular physiology, and for modelling human diseases [6-8]. The reason is the conservation of genes between mice and humans, along with the growing repertoire of genetic tools that allow the manipulation of mouse genes to decipher mechanisms underlying physiological and pathophysiological processes. Therefore, we assume that research in mice will provide valuable information on human biology. Although this is true in most studies, 
there is a considerable difference between the physiology of mice and humans that could directly bias the preclinical findings [9].

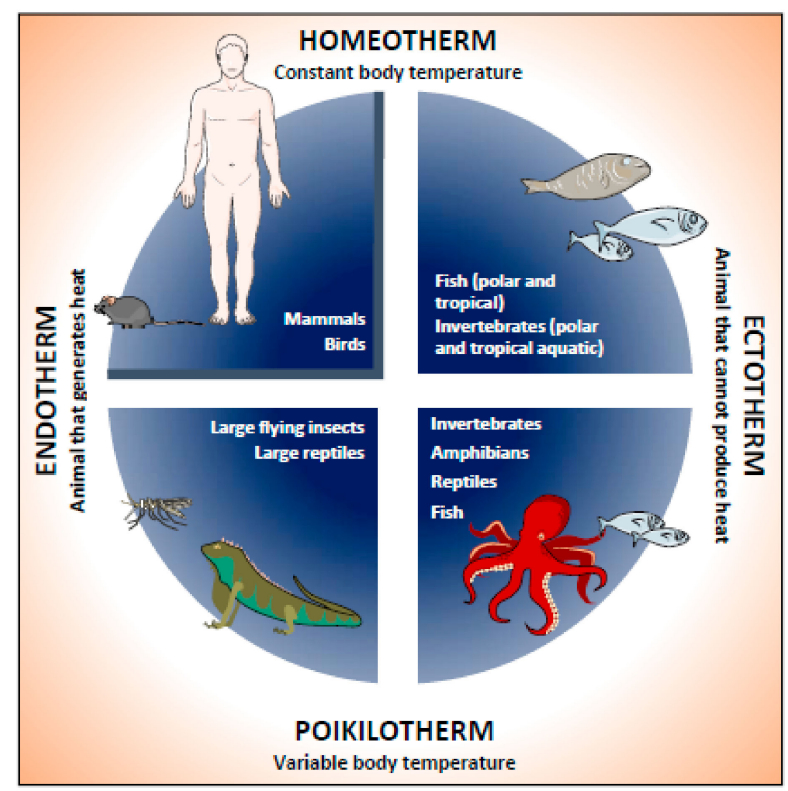

Figure 1. Classification of animals according to their body temperature and adaptation to room temperature. Animals are classified according to their way of acquiring body heat and their ability to adapt to room temperature. Endothermic animals can produce heat endogenously. Ectothermal animals cannot produce their own heat, so they rely on ambient temperature. In addition, animals can be classified into homeotherms that can keep their body temperature constant, or poikilotherms that have a variable body temperature. Humans and mice are mammals that are classified as homeothermal endotherms. However, when subjected to an ambient temperature well below their thermoneutrality, they experience physiological responses that trigger adaptive thermogenesis.

Like other small mammals, the mouse has a large surface area and a small body mass. This makes mice vulnerable to fluctuations in the ambient temperature $\left(T_{a}\right)$, especially when it falls below their thermoneutral temperature $\left(29-31^{\circ} \mathrm{C}\right)$ [9-13]. Mammals try to maintain their core temperature through the adaptive capacity of thermoregulation. Thus, the mouse uses various adaptations to keep thermal homeostasis in colder environments. For instance, the function of brown adipose tissue (BAT) is to maintain body temperature through a process called thermogenesis or heat production. Currently, most metabolic studies involving rodents are carried out at $21^{\circ} \mathrm{C}$, which is a thermoneutral zone in adult humans but is below the thermoneutral zone in mice. As a consequence, research studies in mice that are housed at $21^{\circ} \mathrm{C}$ may not directly apply to humans, who live mainly in their comfort zone or neutrality $[6,7,10]$. For this reason, it is necessary to understand how $\mathrm{T}_{\mathrm{a}}$ affects metabolic and cardiovascular phenotypes in mice, and the importance of this variable in the modelling of human diseases in rodents.

As animal models and measurement techniques become increasingly accurate and sophisticated, environmental variables become critical for research development. A stable, defined environment is essential to generate consistent experimental results that support both replication and valid interpretations of the data. Previous studies have shown how mice adaptation to $T_{a}$ alters their disease phenotype [14-16]. Consequently, $\mathrm{T}_{\mathrm{a}}$ might be a variable to consider in metabolic studies to guarantee valid interpretation of experimental results, consistent conclusions and greater certainty in the translation of preclinical experiments to clinical studies.

The prevention and treatment of obesity has become a health priority. There is an alarming increase in the prevalence of obesity and associated metabolic diseases, including type 2 diabetes mellitus (T2D) and cardiovascular disease [17]. The health and economic impact of monitoring and 
managing obesity and associated complications is also remarkable. Lifestyle changes, such as dietary interventions and/or increased physical activity, have been widely recommended to prevent and treat obesity. However, it is essential to determine why, in general, many obese individuals are exceptionally resistant to treatment and voluntary weight loss is so difficult to achieve and sustain over time. Thus, a better understanding of energy homeostasis is essential.

In this review, we aim to cover important aspects related to the adaptation of animals to $T_{a}$, the influence of $T_{a}$ on the development of metabolic phenotypes in experimental mice, and their translation into human physiology.

\section{Classification of Animals According to Body Temperature and Their Adaptation to Ambient Temperature}

All living beings are sensitive to a minimum, optimum and maximum temperature. Due to environmental adaptations, organisms are conditioned to their habitat in different climatic zones. Accordingly, they are classified into eurytherms (tolerant to a wide variation of external temperatures) and stenotherms (tolerant to a narrow range of ambient temperatures) [18] (Figure 1).

The temperature of an animal is the amount of heat per unit of tissue mass and is a balance between heat production and exchange, a key determinant in reproduction and development [19]. Body temperature $\left(\mathrm{T}_{\mathrm{b}}\right)$ is defined as the reflection of the thermal energy that is retained in the body's molecules. Based on the stability of $\mathrm{T}_{\mathrm{b}}$, animal species can be classified as either poikilotherms or homeotherms [19] (Figure 1). Poikilotherms are animals with a variable $\mathrm{T}_{\mathrm{b}}$, i.e., their temperature changes in response to environmental conditions. In contrast, homeotherms are animals that maintain a relatively stable $T_{b}$. Most homeotherms manage to maintain a constant $T_{b}$ through physiological processes that regulate production rates and heat loss. The difference between poikilotherms and homeotherms depends on the animal's physiology and the nature of the environment. An animal can maintain a constant $T_{b}$ if it inhabits an environment with a constant $T_{a}$. Thermoregulation mechanisms are understood as the physiological strategy that an animal uses to control temperature within the desired range [20]. According to these thermoregulation mechanisms, animals are also described as ectotherms and endotherms (Figure 1).

In addition, animals can control their $\mathrm{T}_{\mathrm{b}}$ through their behavior. Behavioral thermoregulation can be used to control the body temperature of a poikilotherm or to reduce the cost of thermoregulation in a homeotherm [20]. In ectotherms, the environment and behavioral thermoregulation determine the $T_{b}$. In contrast, endotherms are vertebrates that generate internal heat to maintain a given $T_{b}$.

Most mammals and birds (as illustrated in Figure 1) are classified as homeotherms because $T_{b}$ is stable, and endotherms since they thermoregulate $\mathrm{T}_{\mathrm{b}}$ through metabolic heat and the thermal insulation capacity of the animal.

\section{The Use of Experimental Mice as a Model in Human Research}

\subsection{Relationship Between Body Size and Physiological Temperature}

Since the 1990s, genetic mouse models have been used to study obesity and energy balance. The cloning and characterization of mutant genes associated with obesity led to the discovery of proteins such as leptin [21], its receptor [22] and melanocyte-stimulating hormone [23], among others [24-26], that cause monogenic obesity in mice and humans [27]. Together, these studies validated the use of the mouse in the modelling of biological diseases related to energy homeostasis. Nonetheless, in energy homeostasis studies, the thermal physiology of the experimental model of choice must be considered [8]. Mice and humans are both endothermic mammals with the ability to thermoregulate to maintain a constant $T_{b}$. Yet the process of thermoregulation has important physiological differences between the two species that we should bear in mind as researchers. For instance, the size of an animal influences its thermal biology through its surface/volume ratio. The larger the individual is, the smaller the ratio. Body surface area is proportional to the power of $2 / 3$ to mass and it is an important determinant in 
heat loss [28,29]. Adult humans are approximately 3000 times heavier than mice $(75 \mathrm{~kg}$ vs. $25 \mathrm{~g})$. As thermal biology depends on body size, it is important to consider this significant difference in inter-species dimensions. Homeothermic endotherms, such as mice and humans, must dissipate the excess heat produced by their metabolism across the body surface. Humans have a larger body size with a lower relative surface area, which leads to less heat loss. In contrast, mice have a smaller body size for a greater relative surface area, and thus greater heat loss.

Mice and humans have a similar internal $\mathrm{T}_{\mathrm{b}}$ average of $37.0^{\circ} \mathrm{C}$ in humans and $36.6{ }^{\circ} \mathrm{C}$ in mice [30], which is within the characteristic range in mammals. Humans generate heat primarily as a by-product of metabolism, without as much need for additional heat generation mechanisms. In fact, human physiology is mostly aimed at heat dissipation. In contrast, the small size of the mouse means that it can transfer heat quickly and have rapid changes in $\mathrm{T}_{\mathrm{b}}$, so mice require more heat generation capacity to maintain their $\mathrm{T}_{\mathrm{b}}$.

Figure 2 shows the components of energy expenditure depending on $T_{a}$ [28-31]. In the mouse, total energy expenditure is the sum of the basal metabolic rate (BMR), physical activity, food thermogenesis and cold-induced thermogenesis [32]. At a given $T_{a}$, over a third of the total energy expenditure is cold-induced thermogenesis, which is necessary to maintain $T_{b}$. This amount of cold-induced thermogenesis, also called facultative or adaptive thermogenesis, is reduced by the availability of nesting material or by keeping mice grouped in cages so they can snuggle. In contrast, in humans, cold-induced thermogenesis contributes a very small fraction to total energy expenditure [33].

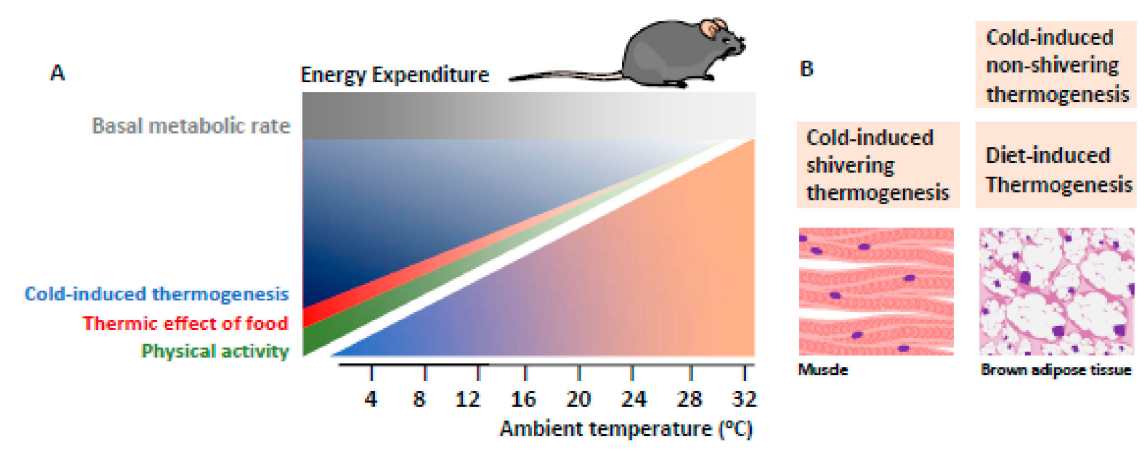

Figure 2. Cellular energy used in adaptive thermogenesis. (A) The total energy expenditure of the mouse can be divided into four components: basal metabolic rate, physical activity (green), the thermal effect of food (red) and cold-induced thermogenesis (blue). At room temperature $\left(20-22{ }^{\circ} \mathrm{C}\right)$ more than one third of the total energy expenditure is cold-induced thermogenesis, which is required to maintain body temperature. (B) The energy used for cold-induced thermogenesis is mainly produced by skeletal muscle shivering and BAT thermogenesis.

\subsection{Thermal Physiology and Thermoneutrality Zone}

Mammals use heat conservation and generation mechanisms to maintain thermal homeostasis, which is reflected in their constant internal temperature [20]. On exposure to a cold environment, several behavioral mechanisms of heat conservation are activated, such as vasoconstriction, piloerection, hunched posture (to reduce the surface area) and snuggling. When these conservative heat adaptations prove insufficient for defense against the cold, mammals increase their energy expenditure to generate heat by involuntary muscle contractions (shivering thermogenesis) and uncoupled respiration in brown adipocytes (non-shivering thermogenesis, known as adaptive or facultative thermogenesis). The opposite occurs when mammals face environmental heat. In this case, there are behavioral adaptations such as vasodilation and increased passive heat loss, as well as panting, licking and sweating (in humans) to increase active heat loss through cooling by evaporation.

Halfway between these metabolic adaptations to a cold environment and heat is the thermoneutral zone, which is defined as the nadir in BMR $[8-10,20]$. When the $T_{a}$ is within the thermoneutral zone, 
BMR generates enough heat to maintain a constant core temperature at $37-38^{\circ} \mathrm{C}$. For young C57BL/6J mice ( 3 months), the thermoneutral zone is between $29-31{ }^{\circ} \mathrm{C}[6,8,10,11]$, which is similar to the thermoneutral zone of a naked human $\left(\sim 28^{\circ} \mathrm{C}\right)$ [34-36]. However, the thermoneutral or comfort zone in dressed humans is around $20-22^{\circ} \mathrm{C}$, which is often the temperature of the animal facilities where the mice are housed. This colder $\mathrm{T}_{\mathrm{a}}$ keeps mice in significant thermal stress or controlled hypothermia, resulting in the activation of facultative thermogenesis in BAT to maintain thermal homeostasis. As a consequence, the BMR and food intake of mice housed at a $\mathrm{T}_{\mathrm{a}}$ of $20^{\circ} \mathrm{C}$ is $\sim 100 \%$ higher than those housed at $30^{\circ} \mathrm{C}$. Both parameters increase by another $\sim 100 \%$ when mice are housed at a $\mathrm{T}_{\mathrm{a}}$ of $4-5^{\circ} \mathrm{C}$ [37]. As discussed in detail below, the chronic housing of mice under thermal stress conditions $\left(\mathrm{T}_{\mathrm{a}}\right.$ of $20-22^{\circ} \mathrm{C}$ ) has profound effects on many physiological phenotypes and their intrinsic ability to adapt to environmental challenges.

Although the thermoneutral zone is considered a standard range, it is a highly variable parameter that differs between species. Previous studies showed that the thermoneutral zone of a particular mammal reflected its adaptations to its natural habitat [9].

In addition to these differences between species, many parameters can affect the range of the thermoneutral zone and the cold tolerance within a given species. For example, age (newborn and young mice have higher thermoneutral zones), muscle mass (basal metabolism and heat production are proportional to muscle mass), locomotor activity (exercise increases the production of heat to decrease the thermoneutral zone), pregnancy (fetal metabolism increases heat production), lactation (milk production generates heat), and isolation (greater isolation reduces the increase in metabolic rate at lower temperatures) can dynamically modulate the thermoneutral zone and the susceptibility of the organism to a cold environment [9-11]. This variation in the thermoneutral zone explains the differences observed in the cold tolerance of some mutant animals [11], such as those lacking hair, skin or subdermal fat [38-42]. This evidence suggests that experimental determination of thermoneutrality is necessary to understand how genetic mutations in mice affect physiology and disease susceptibility.

\subsection{Thermal Variations in the Housing of Experimental Mice}

In the animal facility, mice can consume unlimited food to meet the energy requirements of adaptive thermogenesis. However, it is known that "control" mice (wild-type experimental mice fed ad-libitum and without physical activity) become sedentary, obese and glucose intolerant and the implications for data misinterpretation in human studies is known [43]. The researchers stated that lack of exercise and unlimited access to food are the factors that most influence the inadequate interpretation of results. Other studies indicate that the underlying role of cold ambient temperatures is the cause of excessive intake and metabolic disorders [6,7,44]. A clearly defined stable environment is essential to generate consistent experimental results that support both replication and valid interpretations of the data. As animal models and measurement techniques become increasingly precise, environmental influences become critical in experimental development. Current technology can detect subtle effects that may have been part of the experimental background previously.

There are many varieties of rodent cages (for example, open lid, closed lid, ventilated and unventilated) that may vary in size, bedding, enrichment devices and other attributes. Even the position of the cage on a shelf can influence the result of the behavioral tests [7]. Another attribute that is rarely considered is the color of the cage. A few years ago, it was shown that this fundamental characteristic of the environment significantly influences circadian metabolic measures in rats [45,46]. The cage dye (transparent, amber, blue or red) causes a significant variation in maximum levels and maximum durations of melatonin during the dark phase and significant changes in the circadian moment of insulin spikes [46].

A fundamental characteristic of the rodent cage is the bedding. The properties of different types of rodent beds can differentially influence the environment of the cage, the physiology and behavior of rodents and even the health of the animals [47-51]. 
$T_{a}$ is another critical feature of the rodent cage environment that is probably influenced by the type of cage system used. Some studies show how the $T_{a}$ interacts with the cage system and possibly with tumor growth $[12,52]$. For example, one study evaluated the thermogenesis of BAT in nude and SCID mice that were individually housed at a $\mathrm{T}_{\mathrm{a}}$ of $21^{\circ} \mathrm{C}$ in ventilated cages with or without shelter or in a static (non-ventilated) cage. The results showed that, independently of the strain, mice individually housed in ventilated cages without shelter had significantly higher BAT thermogenesis and higher adrenal weights than mice housed in static cages or in ventilated cages with shelter. In addition, when tumor cells were implanted, mice housed in static cages had greater tumor growth than mice under the other two conditions. The authors concluded that mice housed in ventilated cages without shelter experienced cold stress, which in turn interfered with tumor growth [12]. Another study reported that $\mathrm{BALB} / \mathrm{c}$ and $\mathrm{C} 57 \mathrm{BL} / 6$ mice housed 5 per cage at a $\mathrm{T}_{\mathrm{a}}$ of $22^{\circ} \mathrm{C}$ had higher tumor growth than those maintained at $30^{\circ} \mathrm{C}$ but did not detect a temperature effect on tumor growth when they used nude mice and SCID with immunodeficiency. The study also determined that the antitumor immune response was attenuated in immunodeficient mice maintained at $21^{\circ} \mathrm{C}$ compared to those housed at $30^{\circ} \mathrm{C}[52]$.

Another variable to consider is the density of mouse housing. For some studies, individual housing is preferred or necessary, while in other cases, rodents can be accommodated in groups that vary in number and density depending on the type of cage, the duration of the study, the purpose of the study and other factors. An important fact to consider is that not all mice housed in the same cage are necessarily identical, even if they are highly inbred. The differences between cage mates can be visually obvious in cages with domination hierarchies, which can occur in association with fights and overt injuries in some cage mates but not in others. Mice housed in groups may show greater phenotypic variation in some characteristics than mice housed individually from the same inbred strain [53].

Rodent housing density can directly affect the environmental conditions within the cage and, therefore, potentially alter the physiology, behavior of animals [54] and stress levels [55,56]. An interesting study evaluated the effect of the number of mice in a cage on the inside environment. Mice were housed in stable cohorts of one or five per cage, or in a test cage that initially contained five mice. One mouse was removed per week from the test cage until only one was left. Regardless of the room temperature $\left(22^{\circ} \mathrm{C}, 26^{\circ} \mathrm{C}\right.$ or $\left.30^{\circ} \mathrm{C}\right)$, cages containing five mice were general approximately $1.5^{\circ} \mathrm{C}$ warmer than cages with individual mice, and a population of approximately three mice was associated with a decrease in temperatures and dew point inside the cage [57]. These findings are particularly relevant for situations in which individual mice are removed from a cage for some reason (for example, death, fighting and experimental use) because the remaining mice will experience different environmental conditions that could influence the experimental results [57].

Social housing can also affect the physiology and behavior of animals [58-60]. For example, a study that evaluated sleep, temperature and activity compared these measures in mice initially housed as part of a trio, then individually and finally individually with access to a shelter [60]. The data showed that the modifications in housing significantly influenced both the sleep and activity of mice. When housed individually, mice showed less rapid eye movement sleep and more locomotive activity during the dark phase than when they were housed as part of a trio. When given a shelter, the same mouse spent more time in slow wave sleep and was less active during the dark phase.

Thus, researchers should keep in mind that eliminating mice during an experiment could affect metabolism, as well as many of the other temperature-sensitive biological and physiological responses that have been analyzed so far. This probably contributes to experimental variability between experiments and laboratories.

\section{Neuronal Control of Body Temperature}

Homeostatic control of the $T_{b}$ is essential for the survival of mammals. It is well-established that $\mathrm{T}_{\mathrm{b}}$ is regulated partly by specific neuronal populations located in the hypothalamus [61]. This part of 
the brain works as a thermostat to maintain the $T_{b}$ within a narrow range [62]. The most important regions of the hypothalamus involved in $\mathrm{T}_{\mathrm{b}}$ regulation are the preoptic area (POA) and the posterior hypothalamic area (Figure 3) [63]. They contain temperature-sensitive neurons that initiate neuronal responses for heat generation or heat dissipation. This means that the brain itself is an input to regulate homeostatic responses. These conclusions are based on results obtained from electrophysiological recordings of the POA and revealed that local or environmental heat activate a subset of neurons referred to as "warm-sensitive" [8,64,65].

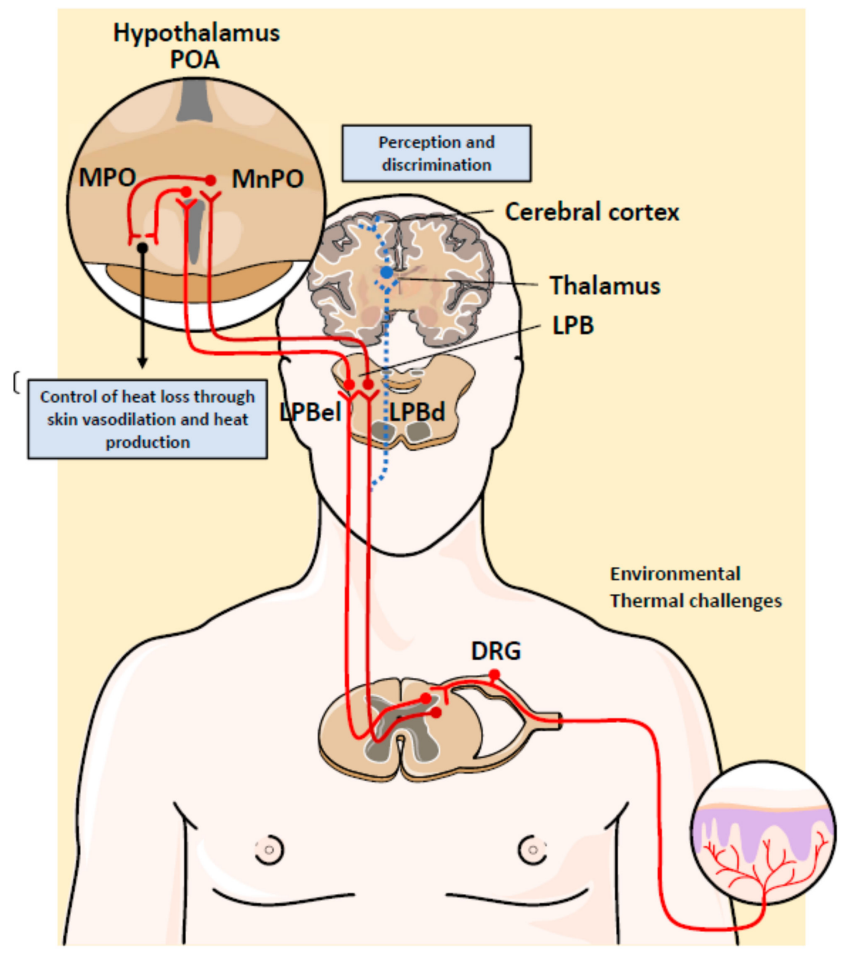

Figure 3. Hypothalamic thermoregulatory network that controls body temperature in mammals. The hypothalamic neurons of the preoptic area (POA) and the posterior hypothalamic area function as a body thermostat to maintain a stable body temperature. The ascending temperature information ends in two anatomically distinct areas of the lateral parabrachial nucleus (LPB): the lateral and dorsal external LPB (LPBel and LPBd, respectively). Heat and cold have been shown to activate cFOS expression in LPBd and LPBel, respectively. Altogether, this sophisticated thermoregulatory network highlights the importance of maintaining body temperature during an environmental temperature challenge. DRG, dorsal root ganglia; MPO, medial preoptic subnucleus; $\mathrm{MnPO}$, median preoptic subnucleus.

In addition to sensing local brain temperature, POA neurons receive thermal information from the periphery. It has been reported that three tissues provide an important input: the skin, spinal cord, and abdominal viscera [66]. The thermosensitivity of these tissues is due to sensory neurons that measure the temperature. Most of the neurons have cell bodies located in dorsal root ganglia (DRG) and their axons extend out to the target tissues [67]. Considerable progress has been made to elucidate the molecular basis of peripheral cold and warmth sensing. These studies have led to the identification of a number of ion channels activated by a wide spectrum of physical and chemical stimuli. Those activated by temperature belong to a superfamily of ion channels called transient receptor potential (TRP) channels $[68,69]$. Four TRP subtypes are activated by an increase in temperature and two TRP channels are activated by decreases in temperature [68]. For example, TRPM8 is an ion channel that admits $\mathrm{Ca}_{2}{ }^{+}$and $\mathrm{Na}^{+}$in response to moderate cold $\left(10-25^{\circ} \mathrm{C}\right)$, while several transient receptor potential cation channels (TRV) have been proposed to sense warmth including TRVP1, TRVP3, TRCP4 and TRVP2 [70]. The mechanism by which temperature modulates TRP channels remains to be elucidated. 
Temperature information is sensed by these thermoreceptors in DRG neurons and is then transmitted to the dorsal horn of the spinal cord, where it is further processed before being sent to the brain (Figure 3). Elegant experiments have been carried out to elucidate the role of these thermosensitive neurons. Transgenic mice lacking TRVP1 in temperature-sensitive DRG neurons have reduced spinal neuron responses to heat [71]. Similarly, ablation of TRPM8+ DRG neurons reduced the number of spinal neurons activated by mild cold, but not by lower temperatures [72]. These results support the idea that spinal neurons synthesize information from many types of DRG neurons.

Dorsal horn neurons send glutamatergic projection to the brain that synapse with the lateral parabrachial nucleus (LPB) and the thalamus. Thermal information received in the thalamus is relayed upward to the somatosensory cortex and other cortex areas, where it mediates the discrimination of temperature (spinothalamocortical pathway) [73]. The ablation of this thermosensory pathway does not affect the autonomic response of $T_{b}$ regulation. However, injuring or silencing of the LPB abolishes autonomic responses to skin cooling and warming and the temperature preference in behavioral assays [74]. This result suggests that the spinothalamocortical pathway does not play a role in the thermal afferent pathway that evokes involuntary thermoregulatory responses to environmental challenges.

Ascending temperature information terminates in two anatomically distinct areas of LPB: the external lateral and dorsal LPB (LPBel and LPBd). It has been demonstrated that warm and cold activate cFOS expression in LPBd and LPBel, respectively [75]. LPB neurons send glutamatergic projections to the midline POA, where GABAergic and glutamatergic interneurons in the median preoptic (MnPO) subnucleus are activated [76]. LPBel neurons activate GABAergic MnPO interneurons that inhibit the distinct population of warm-sensitive neurons in the medial preoptic (MPO) subnucleus that control cutaneous vasoconstriction, BAT and shivering. Thus, inhibition of neurons in the MPO increases core body temperature, shivering, metabolism and heart rate. In contrast, glutamatergic interneurons in the $\mathrm{MnPO}$, which may be excited by glutamatergic inputs from warm-activated neurons in LPDd, excite warm sensitive neurons in MPO [61,77]. Altogether, this thermoregulatory network is a sophisticated reflex that is necessary to maintain $T_{b}$ during an environmental temperature challenge (Figure 3 ).

\section{Adaptive Thermogenesis in Brown Adipose Tissue}

Small mammals have a tissue dedicated to heat generation, the BAT [78]. For a long time, it was known that BAT was present in small mammals such as rodents and neonatal humans. However, in the last decade it was discovered that active BAT is also found in adult humans [79].

In rodents, BAT is located mainly in the interscapular zone. In adult humans, it is found in the supraclavicular region, and in the cervical, axillary, paravertebral and perirenal areas [80]. BAT is called "classic" to distinguish it from inducible or beige adipose tissue, which has unique molecular and developmental characteristics [81]. Beige adipocytes have the appearance of white adipose tissue (WAT) until the animal needs to generate more heat. After exposure to cold or other stimuli, this beige adipose tissue or inducible BAT is enriched in cells with the appearance and functional characteristics of classic BAT in a process called browning. Although beige and BAT adipose tissue have different developmental origins and gene expression profiles [82], both are thermogenic. Thermogenic adipocytes can increase energy expenditure and generate heat by uncoupling the oxidative metabolism from ATP production. This function is carried out by the uncoupling protein (UCP)1, a proton transporter located in the internal mitochondrial membrane that uncouples energy generation from fuel oxidation from ATP production to produce heat. Thus, the electrochemical gradient generated through the electron transport chain (ETC) is dissipated [83-85]. In brown adipocytes, the high content of mitochondria and their vascular and nervous supply facilitates thermogenesis activated by the sympathetic nervous system. The nerve terminals act on $\alpha$-adrenergic receptors to promote thermogenesis in BAT. It has been shown that cold enhances sympathetic signaling and that chronic exposure to cold triggers the expansion and activation of BAT [86], resulting in adaptive thermogenesis. 
Adaptive thermogenesis is a mechanism of metabolic heat production that involves stimulation of the sympathetic nervous system to release norepinephrine (NE) and epinephrine, resulting in the increased metabolic activity necessary for heat generation in BAT $[10,79]$. Previous studies have shown that heat production by adaptive thermogenesis in mice can triple that of basal metabolism, and it is what increases the most in other animal models $[87,88]$.

Obesity is an important risk factor for type 2 diabetes and cardiovascular disease. Importantly, BAT has been shown to promote HDL turnover and reverse cholesterol transport [89]. The high metabolic activity of thermogenic adipocytes confers atheroprotective properties through increased systemic cholesterol flow through the HDL compartment.

The thermogenic function of BAT requires an adaptive increase in proteasomal activity to ensure the quality control of cellular proteins. It has been shown that ER-localized transcription factor nuclear factor erythroid-2, like-1 (Nfe211 protein, also known as Nrf1) is an important mediator of brown adipocyte function, providing a greater proteometabolic quality control to adapt to cold or obesity [90]. It has been described that obesity might affect BAT's proteasomal activity [90]. A recent epigenomic study associated an altered methylation pattern of the human NFE2L1 locus with BMI [91]. However, the molecular mechanism implicated in how this epigenetic variant could affect Nrf1 and proteasome activity is still unknown.

\section{Therapeutic Efficacy of Adaptive Thermogenesis in Obesity}

In recent decades, BAT has been extensively investigated for its potential therapeutic role in obesity and T2D. Previous studies showed that excessive caloric intake could stimulate the expansion of BAT and the increase in thermogenesis as an adaptive measure to maintain body weight. This mechanism of diet-induced thermogenesis is mediated by BAT and UCP1 [92]. In fact, in the absence of UCP1, mice are prone to obesity. Initial studies, where brown adipocytes were genetically ablated with a toxin driven by the UCP1 promoter [93], demonstrated for the first time the protective effect of BAT against obesity and T2D. Importantly, these protective effects were observed in mice raised at room temperature (thermal stress with a $\mathrm{T}_{\mathrm{a}}$ of $20-22{ }^{\circ} \mathrm{C}$ ). Subsequent investigations under $\mathrm{T}_{\mathrm{a}}$ conditions showed that $U \mathrm{cp} 1^{-/-}$mice were very susceptible to hypothermia, due to recurrent tremors, but did not demonstrate the role of UCP1 in thermogenesis, nor a propensity to develop obesity [94,95]. However, when mice remained at thermoneutrality, they showed greater metabolic efficiency, which resulted in an increase in adiposity and obesity development [96]. This is explained because UCP1 knockout mice are more susceptible to hypothermia, which directly affects most of the systemic effects of energy metabolism [93].

The preferable fuel source in BAT is lipids, but glucose is also used. Therefore, approaches to activate BAT and reduce glucose and lipid content through adaptive thermogenesis could be potential therapies to fight against obesity [83]. The best way to model human energy physiology with mice is under thermoneutral $\left(30^{\circ} \mathrm{C}\right)$ conditions. Under this situation, cold-induced thermogenesis would be minimal and will not influence total energy expenditure [97]. Other potential variables that may account in similar proportions for total energy expenditure compared with a sedentary human would be BMR (70\%), food thermogenesis (10\%) and energy expenditure by physical activity (20\%) [7]. Because energy expenditure decreases by approximately $50 \%$ in mice at thermoneutrality [98], this implies that the metabolic phenotype in obesity including adiposity would be highly dependent on the $T_{a}$. An example of this implication is shown in a study about thyroid hormone metabolism [99]. In humans, hyperthyroidism is associated with a hypermetabolic state, characterized by heat intolerance and fat loss, while hypothyroidism decreases energy expenditure and promotes cold intolerance and obesity. Interestingly, the authors have shown that unlike in humans with hypothyroidism, mice that lack type 2 deiodinase, a key enzyme in the conversion of thyroid hormone, did not develop metabolic dysfunction when housed at $22^{\circ} \mathrm{C}$. However, when these animals were maintained at thermoneutrality $\left(30^{\circ} \mathrm{C}\right)$, there was an increase in adiposity, hepatic steatosis and glucose intolerance [99]. Therefore, they concluded that the accommodation of mice at a $\mathrm{T}_{\mathrm{a}}$ resulted in increased adrenergic activity in BAT, 
which compensated for the loss of activity of deiodinase type 2 and the production of T3. These findings suggest that chronic housing of mice under conditions of thermal stress can mask the genetic functions involved in energy balance and metabolic homeostasis triggering a change in the metabolic phenotype.

\subsection{Activating BAT to Treat Obesity}

Obesity is a chronic metabolic disorder characterized by ectopic fat deposition and a state of chronic low-grade inflammation. It is associated with higher free fatty acids, glucose and insulin levels. Adipose tissues, both WAT and BAT, are highly affected during obesity. These alterations include adipocyte hyperplasia and hypertrophy [100], endoplasmic reticulum stress [101], oxidative stress [102], fibrosis [100] and mitochondrial dysfunction [103], among others. Obesity is associated with severe disorders such as cardiovascular disease, dyslipidemia, T2D or even some forms of cancer. BAT was initially recognized for its ability to protect animals from hypothermia [104]. However in the last decade, the discovery that BAT is active in adult humans and that it is reduced in several conditions such as obesity, T2D and aging has triggered leading research in the BAT field to improve lipid and glucose homeostasis in the fight against obesity [105-109].

Overfeeding activates BAT's diet-induced thermogenesis [92]. Thus, several studies have focused on natural or chemical drugs to enhance thermogenesis such as ginger [110], tea seed oil [111], berberine [112], butein [113], capsaicin [114], flavonoids such as quercetin [115], calcium supplement [116] or fluvastatin sodium [117], among others.

Exercise is another inductor of BAT thermogenesis [118]. Interestingly, a positive correlation has been demonstrated between exercise and increased browning in subcutaneous WAT [119]. The lactate produced in muscles after exercise or after cold exposure leads to an increase in UCP1 levels in the adipose tissue [120]. Recently, Takahashi et al. demonstrated that subcutaneous WAT-derived TGF- $\beta 2$ secreted after exercise or its administration improved glucose homeostasis and insulin sensitivity by increasing fatty acid oxidation [121]. Furthermore, some myokines related to BAT activation, such as irisin [122] or $\beta$-aminoisobutyric acid, have been shown to decrease weight gain and improve glucose tolerance in mice [123].

As mentioned above, BAT is innervated by the sympathetic nervous system and controlled by adrenergic inductors such as norepinephrine. Thus, huge efforts have been made to find novel $\beta$-adrenergic agonists that can potentiate BAT activity and enhance thermogenesis. Some examples are Cl-316,243 [124] or mirabegron [125]. The latter was initially clinically used for overactive bladder but was also found to activate BAT in rats and humans [126]. Many other studies have focused on increasing the BAT mass, i.e., the differentiation of brown adipocytes or WAT browning. One study centered on fibroblast growth factor-21 (FGF21) [127], which is mainly secreted by the liver and associated with BAT activity. In humans higher FGF21 levels have been found in serum after cold exposure [128]. Another important thermogenic coactivator is PGC1- $\alpha$, which is involved in mitochondrial biogenesis and thermogenesis [129]. Its activity is related to an increase in other transcriptional factors involved in brown differentiation such as PRDM16 or the PPARs family [130]. Other factors have also been studied to enhance thermogenesis in obesity such as the bone morphogenetic proteins (BMPs) family, for example BMP7 [131] or BMP8b [132]. Interestingly, although BMP4 improves the obese phenotype, it has a tissue-dependent dual effect: it increases browning in subcutaneous WAT; and it increases the number of lipid droplets and decreases BAT UCP1 expression [133]. Another approach to activate thermogenesis has been based on PPAR- $\gamma$ agonists. Some studies showed increased UCP1 levels after treatment with rosiglitazone $[134,135]$. Other secreted peptides or hormones have been reported to activate BAT: norepinephrine [136], natriuretic peptides [137], meteorin-like [138], bile acids, adenosine [139] or activin E [140,141].

In recent years, BAT-derived adipokines, commonly called batokines, have generated considerable interest among the scientific community for their anti-obesity potential [142]. In 2018, Deshmukh et al. found a batokine called EPDR1 involved in BAT activation [143]. Another recent and elegant study has 
discovered a new chemokine called CXCL14 that is secreted by BAT and induces browning of WAT via immune cell activation [144].

Finally, alternative therapies are being studied to increase BAT mass and thermogenesis. These include the direct transplantation of this tissue or differentiated beige cells from preadipocytes, mesenchymal stem cells (MSCs) or induced pluripotent stem cells (iPSC) [145]. In the future, more personalized therapies could focus on the intrinsic study of the genome to identify other BAT activators such as miRNAs to combat obesity [146].

\subsection{Role of Thermoneutrality in Obesity and Metabolic Studies: Chronic Cold vs. Thermoneutrality}

It is known that an increase in metabolic heat production has physiological effects. In fact, for every $1{ }^{\circ} \mathrm{C}$ that the $\mathrm{T}_{\mathrm{a}}$ drops, approximately $46.3 \mathrm{kcal} / \mathrm{m}^{2} / 24 \mathrm{~h}$ are required to maintain the core temperature of the mouse [13]. This increase in metabolic heat production has many physiological effects. For example, energy expenditure is approximately $50 \%$ lower in mice living at thermoneutrality than in mice living in chronic cold conditions [98]. Therefore, we can deduce that the metabolic phenotypes of obesity and adiposity are highly dependent on the $\mathrm{T}_{\mathrm{a}}$ at which mice are housed (Figure 4).

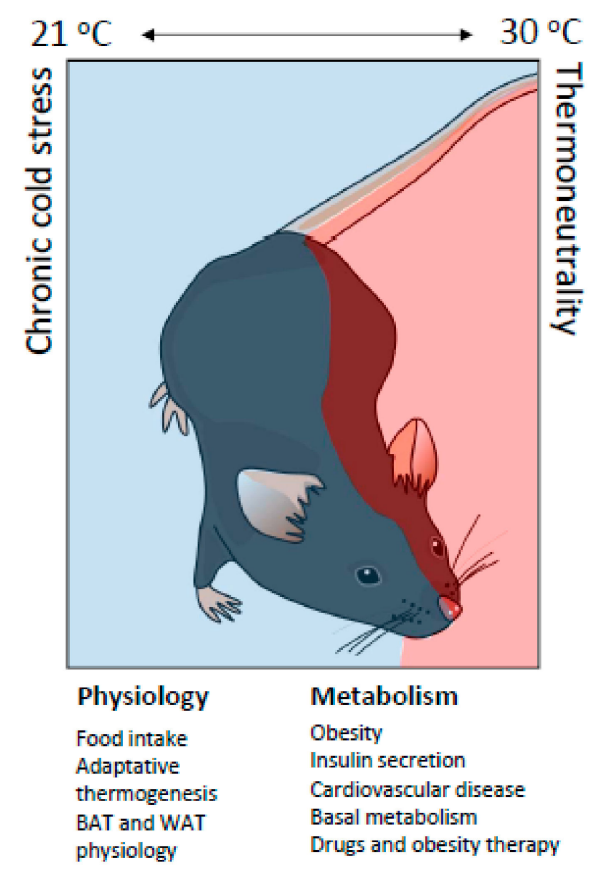

Figure 4. Metabolic and physiological differences in mice under chronic cold or at thermoneutrality. Mouse models used to study metabolic diseases are influenced by environmental temperature. Mice show differences in the metabolic phenotype when housed at a standard temperature $\left(21^{\circ} \mathrm{C}\right)$ vs. thermoneutrality $\left(30^{\circ} \mathrm{C}\right)$. Mice at standard temperatures are subjected to chronic cold. This triggers controlled hypothermia where energy expenditure is affected by changes in physiology (food intake, BAT and WAT physiology and an increase in adaptive thermogenesis) and in metabolism (basal metabolism, adaptive thermogenesis, diet efficiency, insulin secretion, adipose tissue physiology, inflammation at adipocyte and vascular levels, and the effect of drugs and therapies against obesity).

Some studies have shown that the lack of efficient induction of the obese phenotype by high fat diet (HFD) is due to the fact that mice were housed in conditions below their thermoneutrality [57-60]. This effect of low temperatures on obesity has been observed in other animal models $[14,78,81]$, demonstrating the correlation between low temperature and low effectiveness of the diet, as well as low levels of insulin and glucose and an altered response in glucose tolerance tests and energy homeostasis [10,44]. 
Other researchers found differences in metabolic inflammation [84]. Mice housed at thermoneutrality vs. chronic cold had greater metabolic inflammation. This was correlated with higher inflammation in the WAT and at vascular level, promoting atherosclerosis. The authors thus claim that thermal stress could limit our ability to faithfully model human diseases in mice [84].

The exposure to chronic cold vs. thermoneutrality has also been studied at the pharmacological level in obesity. The chemical protonophore, 2,4-dinitrophenol (DNP) was used for weight loss in humans. However, its consumption was discontinued due to toxicity $[45,46]$. DNP generates heat by uncoupling mitochondria. Thus, its anti-obesity mechanism is at least due to an increase in energy expenditure, without a direct effect on food intake. At $22{ }^{\circ} \mathrm{C}$, chronic treatment in mice with a low dose of DNP had no effect on the phenotype and the only change observed was that BAT became less active [47]. This indicates that adaptive cold-induced thermogenesis was potentially reduced by the amount of heat that was generated by DNP-mediated uncoupling [147]. When the same experiment was performed at thermoneutrality, the same dose of DNP increased energy expenditure, reduced body weight, reduced adiposity and improved glucose tolerance [47]. Although DNPs have been discontinued for the treatment of obesity [46], they could serve as a model for the effects of systemic uncoupling agents, which demonstrate better efficacy at thermoneutrality than at colder temperatures.

Another comparison of the pharmacological effect at chronic cold vs. thermoneutrality is

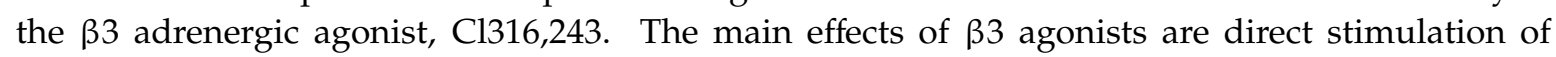
BAT thermogenesis and WAT lipolysis [52]. These experiments were performed at $22{ }^{\circ} \mathrm{C}$, and the pharmacological treatment showed no effect on body weight or adiposity. However, there was greater energy expenditure compensated with the increase in food intake [52]. At thermoneutrality, $\mathrm{Cl316,243}$ increased energy expenditure, but it also reduced body weight and adiposity.

Altogether, it is clear that the $\mathrm{T}_{\mathrm{a}}$ used in experiments with mice is critical and might directly influence the efficiency and clinical translatability of pharmacological, metabolic and energy homeostasis studies.

\section{Conclusions and Future Perspectives}

The mouse is the predominant model for studying human diseases. However, many studies fail to deliver mechanistic information about human physiology. This failure comes from translating preclinical studies in mice to therapy in humans. Although we are aware that mice and humans are two different species, we do not always consider all the external variables of the environment, which could influence the physiological adaptation of the study model and hinder the reproducibility of preclinical investigations.

The thermoregulatory network triggered by the hypothalamus is a necessary reflex to maintain $T_{b}$ during variations in $T_{a}$. Therefore, given the influence that $T_{a}$ exerts on the physiological and pathophysiological responses of the mouse, this study variable should be considered for more correct, efficient translation into human therapy.

The epidemic of obesity and metabolic diseases is increasing exponentially, and current therapies remain inefficient. BAT has become an attractive potential target to treat obesity due to its thermogenic capacity. However, environmental variables such as temperature could directly influence both BAT activity and the dynamics of energy expenditure in the model under study.

For future metabolic studies, it would be important to consider all the variables that may influence the experimental outcome regarding obesity and insulin resistance. For example, an important point is the selective breeding of mouse animal models. Relevant specific differences in metabolic activity have been found in strain-dependent genetic conditions [148-150]. However, the correlation between strain variables and thermo-neutrality in studies of obesity and associated diseases is still unknown.

Currently, most metabolic studies are carried out at a room temperature of $21^{\circ} \mathrm{C}$, which is considered a thermoneutral zone for adult humans. However, mice subjected to the same temperatures experience chronic cold. The cold triggers-controlled hypothermia in which energy expenditure is affected by the increase in adaptive thermogenesis, by the activation of BAT and tremors due to 
involuntary muscle contractions (Figure 4). Further studies in mice at thermoneutrality will deepen our understanding of physiological mechanisms, which could increase the success of translation into human treatments for obesity and metabolic diseases.

Author Contributions: All authors contributed equally to this work. All authors have read and agreed to the published version of the manuscript.

Funding: This study was supported by the Ministry of Spain (MINECO) (SAF2017-83813-C3-1-R to DS and LH, cofunded by the ERDF), the Centro de Investigación Biomédica en Red de Fisiopatología de la Obesidad y la Nutrición (CIBEROBN) (Grant CB06/03/0001 to DS), the Government of Catalonia (2017SGR278 to DS), and the Fundació La Marató de TV3 (201627-30 to DS). MB-P is a recipient of a CONICYT doctoral fellowship.

Conflicts of Interest: The authors declare no conflict of interest.

\section{References}

1. Lovegrove, B.G. The evolution of endothermy in Cenozoic mammals: A plesiomorphic-apomorphic continuum. Biol. Rev. 2011, 87, 128-162. [CrossRef] [PubMed]

2. Bennett, A.; Ruben, J. Endothermy and activity in vertebrates. Science 1979, 206, 649-654. [CrossRef] [PubMed]

3. Pörtner, H.O. Climate Variability and the Energetic Pathways of Evolution: The Origin of Endothermy in Mammals and Birds. Physiol. Biochem. Zoöl. 2004, 7, 959-981.

4. Wu, C.-W.; Storey, K.B. Life in the cold: Links between mammalian hibernation and longevity. Biomol. Concepts 2016, 7, 41-52. [CrossRef] [PubMed]

5. Bouma, H.R.; Verhaag, E.M.; Otis, J.P.; Heldmaier, G.; Swoap, S.J.; Strijkstra, A.M.; Henning, R.H.; Carey, H.V. Induction of torpor: Mimicking natural metabolic suppression for biomedical applications. J. Cell. Physiol. 2012, 227, 1285-1290. [CrossRef] [PubMed]

6. Maloney, S.K.; Fuller, A.; Mitchell, D.; Gordon, C.; Overton, J.M. Translating Animal Model Research: Does It Matter That Our Rodents Are Cold? Physiology 2014, 29, 413-420. [CrossRef] [PubMed]

7. Karp, C.L. Unstressing intemperate models: How cold stress undermines mouse modeling. J. Exp. Med. 2012, 209, 1069-1074. [CrossRef]

8. Gordon, C. Thermal physiology of laboratory mice: Defining thermoneutrality. J. Therm. Biol. 2012, 37, 654-685. [CrossRef]

9. Gordon, C.J. Temperature Regulation in Laboratory Rodents; Cambridge University Press (CUP): Cambridge, UK, 1993.

10. Cannon, B.; Nedergaard, J. Nonshivering thermogenesis and its adequate measurement in metabolic studies. J. Exp. Biol. 2011, 214, 242-253. [CrossRef]

11. Nedergaard, J.; Cannon, B. The Browning of White Adipose Tissue: Some Burning Issues. Cell Metab. 2014, 20, 396-407. [CrossRef]

12. David, J.M.; Chatziioannou, A.F.; Taschereau, R.; Wang, H.; Stout, D.B. The Hidden Cost of Housing Practices: Using Noninvasive Imaging to Quantify the Metabolic Demands of Chronic Cold Stress of Laboratory Mice. Comp. Med. 2013, 63, 386-391.

13. David, J.M.; Knowles, S.; Lamkin, D.M.; Stout, D.B. Individually Ventilated Cages Impose Cold Stress on Laboratory Mice: A Source of Systemic Experimental Variability. J. Am. Assoc. Lab. Anim. Sci. 2013, 52, 738-744. [PubMed]

14. Gouveia, K.; Hurst, J.L. Reducing Mouse Anxiety during Handling: Effect of Experience with Handling Tunnels. PLoS ONE 2013, 8, 1-8. [CrossRef]

15. Greenberg, G.D.; Howerton, C.L.; Trainor, B.C. Fighting in the home cage: Agonistic encounters and effects on neurobiological markers within the social decision-making network of house mice (Mus musculus). Neurosci. Lett. 2014, 566, 151-155. [CrossRef] [PubMed]

16. Haemisch, A.; Gärtner, K. Effects of cage enrichment on territorial aggression and stress physiology in male laboratory mice. Acta Physiol. Scand. Suppl. 1997, 640, 73-76. [PubMed]

17. Tabarés Seisdedos, R. Health effects of overweight and obesity in 195 countries over 25 years. New Engl. J. Med. 2017, 377, 13-27.

18. Pörtner, H.O.; Storch, D.; Heilmayer, O. Constraints and trade-offs in climate-dependent adaptation: Energy budgets and growth in a latitudinal cline. Sci. Mar. 2005, 69, 271-285. [CrossRef] 
19. Flouris, A.D.; Piantoni, C. Links between thermoregulation and aging in endotherms and ectotherms. Temperature 2015, 2, 73-85. [CrossRef]

20. Terrien, J. Behavioral thermoregulation in mammals: A review. Front. Biosci. 2011, 16, 1428. [CrossRef]

21. Zhang, Y.; Proença, R.; Maffei, M.; Barone, M.; Leopold, L.; Friedman, J.M. Positional cloning of the mouse obese gene and its human homologue. Nature 1994, 372, 425-432. [CrossRef]

22. Tartaglia, L.A.; Dembski, M.; Weng, X.; Deng, N.; Culpepper, J.; Devos, R.; Richards, G.J.; Campfield, L.; Clark, F.T.; Deeds, J.; et al. Identification and expression cloning of a leptin receptor, OB-R. Cell 1995, 83, 1263-1271. [CrossRef]

23. Shutter, J.R.; Kinsey, A.C.; Scully, S.; Stark, K.L.; Graham, M.; Lüthy, R. Hypothalamic expression of ART, a novel gene related to agouti, is up-regulated in obese and diabetic mutant mice. Genes Dev. 1997, 11, 593-602. [CrossRef]

24. Ollmann, M.M.; Wilson, B.D.; Yang, Y.-K.; Kerns, J.A.; Chen, Y.; Gantz, I.; Barsh, G.S. Antagonism of central melanocortin receptors in vitro and in vivo by agouti-related protein. Science 1997, 278, 135-138. [CrossRef] [PubMed]

25. Fan, W.; Boston, B.A.; Kesterson, R.A.; Hruby, V.J.; Cone, R.D. Role of melanocortinergic neurons in feeding and the agouti obesity syndrome. Nature 1997, 385, 165-168. [CrossRef] [PubMed]

26. Huszar, D.; Lynch, C.A.; Fairchild-Huntress, V.; Dunmore, J.H.; Fang, Q.; Berkemeier, L.R.; Gu, W.; Kesterson, R.A.; Boston, B.A.; Cone, R.D.; et al. Targeted Disruption of the Melanocortin-4 Receptor Results in Obesity in Mice. Cell 1997, 88, 131-141. [CrossRef]

27. Farooqi, I.S.; O'Rahilly, S. Mutations in ligands and receptors of the leptin-melanocortin pathway that lead to obesity. Nat. Clin. Pr. Endocrinol. Metab. 2008, 4, 569-577. [CrossRef]

28. Kleiber, M. The Fire of Life. An Introduction to Animal Energetics; John Wiley \& Sons, Inc.: London, UK, 1961; p. 454.

29. Schmidt-Nielsen, K.; Knut, S.N. Scaling: Why Is Animal Size so Important? Cambridge University Press: Cambridge, UK, 1984.

30. Refinetti, R. The circadian rhythm of body temperature. Front. Biosci. 2010, 15, 564-594. [CrossRef]

31. Scholander, P.F.; Hock, R.; Walters, V.; Johnson, F.; Irving, L. Heat Regulation in Some Arctic and Tropical Mammals and Birds. Biol. Bull. 1950, 99, 237-258. [CrossRef]

32. Abreu-Vieira, G.; Xiao, C.; Gavrilova, O.; Reitman, M.L. Integration of body temperature into the analysis of energy expenditure in the mouse. Mol. Metab. 2015, 4, 461-470. [CrossRef]

33. Brychta, R.J.; Chen, K.Y. Cold-induced thermogenesis in humans. Eur. J. Clin. Nutr. 2017, 71, $345-352$. [CrossRef]

34. Hill, R.W.; Muhich, T.E.; Humphries, M.M. City-Scale Expansion of Human Thermoregulatory Costs. PLoS ONE 2013, 8, e76238. [CrossRef] [PubMed]

35. Scholander, P.F.; Hammel, H.T.; Andersen, K.L.; Andersen, K.L.; LØyning, Y. Metabolic Acclimation to Cold in Man. J. Appl. Physiol. 1958, 12, 1-8. [CrossRef] [PubMed]

36. E Wilkerson, J.; Raven, P.B.; Horvath, S.M. Critical temperature of unacclimatized male Caucasians. J. Appl. Physiol. 1972, 33, 451-455. [CrossRef] [PubMed]

37. Qiu, Y.; Nguyen, K.D.; Odegaard, J.I.; Cui, X.; Tian, X.Y.; Locksley, R.M.; Palmiter, R.D.; Chawla, A. Eosinophils and type 2 cytokine signaling in macrophages orchestrate development of functional beige fat. Cell 2014, 157, 1292-1308. [CrossRef]

38. Sampath, H.; Flowers, M.T.; Liu, X.; Paton, C.M.; Sullivan, R.; Chu, K.; Zhao, M.; Ntambi, J.M. Skin-specific Deletion of Stearoyl-CoA Desaturase-1 Alters Skin Lipid Composition and Protects Mice from High Fat Diet-induced Obesity. J. Biol. Chem. 2009, 284, 19961-19973. [CrossRef]

39. Hirata, M.; Suzuki, M.; Ishii, R.; Satow, R.; Uchida, T.; Kitazumi, T.; Sasaki, T.; Kitamura, T.; Yamaguchi, H.; Nakamura, Y.; et al. Genetic Defect in Phospholipase C $\delta 1$ Protects Mice From Obesity by Regulating Thermogenesis and Adipogenesis. Diabetes 2011, 60, 1926-1937. [CrossRef]

40. Nakamura, Y.; Fukami, K.; Yu, H.; Takenaka, K.; Kataoka, Y.; Shirakata, Y.; Nishikawa, S.; Hashimoto, K.; Yoshida, N.; Takenawa, T. Phospholipase C $\delta 1$ is required for skin stem cell lineage commitment. EMBO J. 2003, 22, 2981-2991. [CrossRef]

41. Narvaez, C.J.; Matthews, D.; Broun, E.; Chan, M.; Welsh, J. Lean phenotype and resistance to diet-induced obesity in vitamin D receptor knockout mice correlates with induction of uncoupling protein-1 in white adipose tissue. Endocrinology 2009, 150, 651-661. [CrossRef] 
42. Li, Y.C.; Pirro, A.E.; Amling, M.; Delling, G.; Baron, R.; Bronson, R.; DeMay, M.B. Targeted ablation of the vitamin D receptor: An animal model of vitamin D-dependent rickets type II with alopecia. Proc. Natl. Acad. Sci. USA 1997, 94, 9831-9835. [CrossRef]

43. Martin, B.; Ji, S.; Maudsley, S.; Mattson, M.P. “Control” laboratory rodents are metabolically morbid: Why it matters. Proc. Natl. Acad. Sci. USA 2010, 107, 6127-6133. [CrossRef]

44. Overton, J.M. Phenotyping small animals as models for the human metabolic syndrome: Thermoneutrality matters. Int. J. Obes. 2010, 34, S53-S58. [CrossRef] [PubMed]

45. Dauchy, R.T.; Dauchy, E.M.; Hanifin, J.P.; Gauthreaux, S.L.; Mao, L.; Belancio, V.P.; Ooms, T.G.; Dupepe, L.M.; Jablonski, M.R.; Warfield, B.; et al. Effects of Spectral Transmittance through Standard Laboratory Cages on Circadian Metabolism and Physiology in Nude Rats. J. Am. Assoc. Lab. Anim. Sci. 2013, 52, 146-156. [PubMed]

46. A Wren, M.; Dauchy, R.T.; Hanifin, J.P.; Jablonski, M.R.; Warfield, B.; Brainard, G.C.; E Blask, D.; Hill, S.M.; Ooms, T.G.; Bohm, R.P. Effect of Different Spectral Transmittances through Tinted Animal Cages on Circadian Metabolism and Physiology in Sprague-Dawley Rats. J. Am. Assoc. Lab. Anim. Sci. 2014, 53, 44-51. [PubMed]

47. Horn, M.J.; Hudson, S.V.; A Bostrom, L.; Cooper, D.M. Effects of Cage Density, Sanitation Frequency, and Bedding Type on Animal Wellbeing and Health and Cage Environment in Mice and Rats. J. Am. Assoc. Lab. Anim. Sci. 2012, 51, 781-788. [PubMed]

48. Leys, L.J.; McGaraughty, S.; Radek, R.J. Rats Housed on Corncob Bedding Show Less Slow-Wave Sleep. J. Am. Assoc. Lab. Anim. Sci. 2012, 51, 764-768. [PubMed]

49. Royals, M.A.; Getzy, D.M.; Vandewoude, S. High Fungal Spore Load in Corncob Bedding Associated with Fungal-Induced Rhinitis in Two Rats. Contemp. Top. Lab. Anim. Sci. 1999, 38, 64-66. [PubMed]

50. Smith, E.; Stockwell, J.D.; Schweitzer, I.; Langley, S.H.; Smith, A.L. Evaluation of cage micro-environment of mice housed on various types of bedding materials. Contemp. Top. Lab. Anim. Sci. 2004, 43, 12-17.

51. Whiteside, T.E.; Thigpen, J.E.; Kissling, G.E.; Grant, M.G.; Forsythe, D.B. Endotoxin, Coliform, and Dust Levels in Various Types of Rodent Bedding. J. Am. Assoc. Lab. Anim. Sci. 2010, 49, 184-189.

52. Kokolus, K.M.; Capitano, M.L.; Lee, C.-T.; Eng, J.W.-L.; Waight, J.D.; Hylander, B.L.; Sexton, S.; Hong, C.-C.; Gordon, C.J.; Abrams, S.I.; et al. Baseline tumor growth and immune control in laboratory mice are significantly influenced by subthermoneutral housing temperature. Proc. Natl. Acad. Sci. USA 2013, 110, 20176-20181. [CrossRef]

53. Nagy, T.R.; Krzywanski, D.; Li, J.; Meleth, S.; Desmond, R. Effect of Group vs. Single Housing on Phenotypic Variance in C57BL/6J Mice. Obes. Res. 2002, 10, 412-415. [CrossRef]

54. Nicholson, A.; Malcolm, R.D.; Russ, P.L.; Cough, K.; Touma, C.; Palme, R.; Wiles, M.V. The Response of C57BL/6J and BALB/cJ Mice to Increased Housing Density. J. Am. Assoc. Lab. Anim. Sci. 2009, 48, 740-753. [PubMed]

55. Morgan, J.L.; Svenson, K.L.; Lake, J.P.; Zhang, W.; Stearns, T.M.; Marion, M.A.; Peters, L.L.; Paigen, B.; Donahue, L.R. Effects of Housing Density in Five Inbred Strains of Mice. PLoS ONE 2014, 9, e90012. [CrossRef] [PubMed]

56. Paigen, B.; Svenson, K.L.; Von Smith, R.; Marion, M.A.; Stearns, T.; Peters, L.L.; Smith, A.L. Physiological effects of housing density on C57BL/6J mice over a 9-month period. J. Anim. Sci. 2012, 90, 5182-5192. [CrossRef] [PubMed]

57. A Toth, L.; A Trammell, R.; Ilsley-Woods, M. Interactions Between Housing Density and Ambient Temperature in the Cage Environment: Effects on Mouse Physiology and Behavior. J. Am. Assoc. Lab. Anim. Sci. 2015, 54, 708-717. [PubMed]

58. Aghajani, M.; Mahdavi, M.R.V.; Najafabadi, M.K.; Ghazanfari, T.; Azimi, A.; Soleymani, S.A.; Dust, S.M. Effects of Dominant/Subordinate Social Status on Formalin-Induced Pain and Changes in Serum Proinflammatory Cytokine Concentrations in Mice. PLoS ONE 2013, 8, e80650. [CrossRef] [PubMed]

59. Arndt, S.S.; Laarakker, M.C.; Van Lith, H.A.; Van Der Staay, F.J.; Gieling, E.; Salomons, A.R.; Klooster, J.V.; Ohl, F. Individual housing of mice - Impact on behaviour and stress responses. Physiol. Behav. 2009, 97, 385-393. [CrossRef]

60. Febinger, H.Y.; George, A.; Priestley, J.; A Toth, L.; Opp, M.R. Effects of Housing Condition and Cage Change on Characteristics of Sleep in Mice. J. Am. Assoc. Lab. Anim. Sci. 2014, 53, 29-37. 
61. Morrison, S.F.; Nakamura, K. Central neural pathways for thermoregulation. Front. Biosci. 2011, 16, 74-104. [CrossRef]

62. Ranson, S.W. The Hypothalamus as a Thermostat Regulating Body Temperature. Psychosom. Med. 1939, 1, 486-495. [CrossRef]

63. Boulant, J.A. Role of the Preoptic-Anterior Hypothalamus in Thermoregulation and Fever. Clin. Infect. Dis. 2000, 31, 157. [CrossRef]

64. Boulant, J.A.; Hardy, J.D. The effect of spinal and skin temperatures on the firing rate and thermosensitivity of preoptic neurones. J. Physiol. 1974, 240, 639-660. [CrossRef] [PubMed]

65. Tan, C.L.; Cooke, E.K.; Leib, D.E.; Lin, Y.-C.; Daly, G.E.; Zimmerman, C.A.; Knight, Z.A. Warm-Sensitive Neurons that Control Body Temperature. Cell 2016, 167, 47-59. [CrossRef] [PubMed]

66. Jessen, C. Thermal afferents in the control of body temperature. Pharmacol. Ther. 1985, 28, 107-134. [CrossRef]

67. Emery, E.C.; Ernfors, P. Dorsal Root Ganglion Neuron Types and Their Functional Specialization. In The Oxford Handbook of the Neurobiology of Pain; Oxford University Press: Oxford, UK, 2018.

68. Lamas, J.A.; Rueda-Ruzafa, L.; Herrera-Pérez, S. Ion Channels and Thermosensitivity: TRP, TREK, or Both? Int. J. Mol. Sci. 2019, 20, 2371. [CrossRef] [PubMed]

69. Kamm, G.B.; Siemens, J. The TRPM2 channel in temperature detection and thermoregulation. Temperature 2016, 4, 21-23. [CrossRef] [PubMed]

70. Wetsel, W.C. Sensing hot and cold with TRP channels. Int. J. Hyperth. 2011, 27, 388-398. [CrossRef]

71. Ran, C.; Chen, X. Probing the coding logic of thermosensation using spinal cord calcium imaging. Exp. Neurol. 2019, 318, 42-49. [CrossRef]

72. Knowlton, W.M.; Palkar, R.; Lippoldt, E.K.; McCoy, D.D.; Baluch, F.; Chen, J.; McKemy, D.D. A sensory-labeled line for cold: TRPM8-expressing sensory neurons define the cellular basis for cold, cold pain, and cooling-mediated analgesia. J. Neurosci. 2013, 33, 2837-2848. [CrossRef]

73. Craig, A.D.; Bushnell, M.C.; Zhang, E.-T.; Blomqvist, A. A thalamic nucleus specific for pain and temperature sensation. Nature 1994, 372, 770-773. [CrossRef]

74. Yahiro, T.; Kataoka, N.; Nakamura, Y.; Nakamura, K. The lateral parabrachial nucleus, but not the thalamus, mediates thermosensory pathways for behavioural thermoregulation. Sci. Rep. 2017, 7, 5031. [CrossRef]

75. Nakamura, K.; Morrison, S.F. A thermosensory pathway that controls body temperature. Nat. Neurosci. 2007, 11, 62-71. [CrossRef] [PubMed]

76. Tansey, E.A.; Johnson, C.D. Recent advances in thermoregulation. Adv. Physiol. Educ. 2015, 39, 139-148. [CrossRef] [PubMed]

77. Nakamura, K. Central circuitries for body temperature regulation and fever. Am. J. Physiol. Integr. Comp. Physiol. 2011, 301, R1207-R1228. [CrossRef] [PubMed]

78. Cannon, B.; Nedergaard, J. Brown Adipose Tissue: Function and Physiological Significance. Physiol. Rev. 2004, 84, 277-359. [CrossRef] [PubMed]

79. Calderon-Dominguez, M.; Mir, J.F.; Fucho, R.; Weber, M.; Serra, L.; Herrero, L. Fatty acid metabolism and the basis of brown adipose tissue function. Adipocyte 2015, 5, 98-118. [CrossRef] [PubMed]

80. Nedergaard, J.; Bengtsson, T.; Cannon, B. Unexpected evidence for active brown adipose tissue in adult humans. Am. J. Physiol. Metab. 2007, 293, 444-452. [CrossRef]

81. Wu, J.; Cohen, P.; Spiegelman, B.M. Adaptive thermogenesis in adipocytes: Is beige the new brown? Genes Dev. 2013, 27, 234-250. [CrossRef]

82. Ikeda, K.; Maretich, P.; Kajimura, S. The Common and Distinct Features of Brown and Beige Adipocytes. Trends Endocrinol. Metab. 2018, 29, 191-200. [CrossRef]

83. Bartelt, A.; Bruns, O.T.; Reimer, R.; Hohenberg, H.; Ittrich, H.; Peldschus, K.; Kaul, M.G.; I Tromsdorf, U.; Weller, H.; Waurisch, C.; et al. Brown adipose tissue activity controls triglyceride clearance. Nat. Med. 2011, 17, 200-205. [CrossRef]

84. Fedorenko, A.; Lishko, P.V.; Kirichok, Y. Mechanism of fatty-acid-dependent UCP1 uncoupling in brown fat mitochondria. Cell 2012, 151, 400-413. [CrossRef]

85. Krauss, S.; Zhang, C.-Y.; Lowell, B.B. The mitochondrial uncoupling-protein homologues. Nat. Rev. Mol. Cell Biol. 2005, 6, 248-261. [CrossRef] [PubMed]

86. Klingenspor, M. Cold-induced recruitment of brown adipose tissue thermogenesis. Exp. Physiol. 2003, 88, 141-148. [CrossRef] [PubMed]

87. Hart, J.S. Rate of Gain and Loss of Cold Resistance in Mice. Can. J. Zool. 1953, 31, 112-116. [CrossRef] 
88. Kaplan, H.M.; Foster, H. The Mouse in Biomedical Research. Physiology 1983, 111, 248-292.

89. Bartelt, A.; John, C.; Schaltenberg, N.; Berbée, J.F.P.; Worthmann, A.; Cherradi, M.L.; Schlein, C.; Piepenburg, J.; Boon, M.R.; Rinninger, F.; et al. Thermogenic adipocytes promote HDL turnover and reverse cholesterol transport. Nat. Commun. 2017, 8, 15010. [CrossRef] [PubMed]

90. Bartelt, A.; Widenmaier, S.B.; Schlein, C.; Johann, K.; Goncalves, R.L.S.; Eguchi, K.; Fischer, A.W.; Parlakgul, G.; Snyder, N.A.; Nguyen, T.B.; et al. Brown adipose tissue thermogenic adaptation requires Nrf1-mediated proteasomal activity. Nat. Med. 2018, 24, 292-303. [CrossRef] [PubMed]

91. Wahl, S.; Drong, A.; Lehne, B.; Loh, M.; Scott, W.R.; Kunze, S.; Tsai, P.C.; Ried, J.S.; Zhang, W.; Yang, Y.; et al. Epigenome-wide association study of body mass index, and the adverse outcomes of adiposity. Nature 2017, 541, 81-86. [CrossRef] [PubMed]

92. Rothwell, N.J.; Stock, M.J. A role for brown adipose tissue in diet-induced thermogenesis. Obes. Res. 1997, 5, 650-656. [CrossRef]

93. Lowell, B.B.; S-Susulic, V.; Hamann, A.; Lawitts, J.A.; Himms-Hagen, J.; Boyer, B.B.; Kozak, L.P.; Flier, J.S. Development of obesity in transgenic mice after genetic ablation of brown adipose tissue. Nature 1993, 366, 740-742. [CrossRef]

94. Enerbäck, S.; Jacobsson, A.; Simpson, E.M.; Guerra, C.; Yamashita, H.; Harper, M.-E.; Kozak, L.P.; Enerb, S. Mice lacking mitochondrial uncoupling protein are cold-sensitive but not obese. Nature 1997, 387, 90-94.

95. Liu, X.; Rossmeisl, M.; McClaine, J.; Kozak, L.P. Paradoxical resistance to diet-induced obesity in UCP1-deficient mice. J. Clin. Investig. 2003, 111, 399-407. [CrossRef] [PubMed]

96. Feldmann, H.M.; Golozoubova, V.; Cannon, B.; Nedergaard, J. UCP1 Ablation Induces Obesity and Abolishes Diet-Induced Thermogenesis in Mice Exempt from Thermal Stress by Living at Thermoneutrality. Cell Metab. 2009, 9, 203-209. [CrossRef] [PubMed]

97. De Jong, J.M.; Sun, W.; Pires, N.D.; Frontini, A.; Balaz, M.; Jespersen, N.Z.; Feizi, A.; Petrovic, K.; Fischer, A.W.; Bokhari, M.H.; et al. Human brown adipose tissue is phenocopied by classical brown adipose tissue in physiologically humanized mice. Nat. Metab. 2019, 1, 830-843. [CrossRef]

98. Ganeshan, K.; Chawla, A. Warming the mouse to model human diseases. Nat. Rev. Endocrinol. 2017, 13, 458-465. [CrossRef]

99. Castillo, M.; Hall, J.A.; Correa-Medina, M.; Ueta, C.; Kang, H.W.; Cohen, D.E.; Bianco, A.C. Disruption of Thyroid Hormone Activation in Type 2 Deiodinase Knockout Mice Causes Obesity With Glucose Intolerance and Liver Steatosis Only at Thermoneutrality. Diabetes 2011, 60, 1082-1089. [CrossRef] [PubMed]

100. Santry, H.P.; Madore, J.C.; Collins, C.E.; Ayturk, M.D.; Velmahos, G.C.; Britt, L.; Kiefe, C.I. Variations in the implementation of acute care surgery: Results from a national survey of university-affiliated hospitals. J. Trauma Acute Care Surg. 2015, 78, 60-68. [CrossRef]

101. Cnop, M.; Foufelle, F.; Velloso, L.A. Endoplasmic reticulum stress, obesity and diabetes. Trends Mol. Med. 2012, 18, 59-68. [CrossRef]

102. Furukawa, S.; Fujita, T.; Shimabukuro, M.; Iwaki, M.; Yamada, Y.; Nakajima, Y.; Nakayama, O.; Makishima, M.; Matsuda, M.; Shimomura, I. Increased oxidative stress in obesity and its impact on metabolic syndrome. J. Clin. Investig. 2017, 114, 1752-1761. [CrossRef]

103. De Mello, A.H.; Costa, A.B.; Engel, J.D.G.; Rezin, G.T. Mitochondrial dysfunction in obesity. Life Sci. 2018, 192, 26-32. [CrossRef]

104. E Smith, R.; A Horwitz, B. Brown fat and thermogenesis. Physiol. Rev. 1969, 49, 330-425. [CrossRef]

105. McMaster, M.L.; Kristinsson, S.Y.; Turesson, I.; Björkholm, M.; Landgren, O. Novel aspects pertaining to the relationship of Waldenström's macroglobulinemia, IgM monoclonal gammopathy of undetermined significance, polyclonal gammopathy, and hypoglobulinemia. Clin. Lymphoma Myeloma 2009, 9, 19-22. [CrossRef] [PubMed]

106. Saito, M.; Okamatsu-Ogura, Y.; Matsushita, M.; Watanabe, K.; Yoneshiro, T.; Nio-Kobayashi, J.; Iwanaga, T.; Miyagawa, M.; Kameya, T.; Nakada, K.; et al. High incidence of metabolically active brown adipose tissue in healthy adult humans: Effects of cold exposure and adiposity. Diabetes 2009, 58, 1526-1531. [CrossRef] [PubMed]

107. Lichtenbelt, W.D.V.M.; Vanhommerig, J.W.; Smulders, N.M.; Drossaerts, J.M.; Kemerink, G.J.; Bouvy, N.D.; Schrauwen, P.; Teule, G.J. Cold-Activated Brown Adipose Tissue in Healthy Men. New Engl. J. Med. 2009, 360, 1500-1508. [CrossRef] [PubMed] 
108. Virtanen, K.A.; Lidell, M.E.; Orava, J.; Heglind, M.; Westergren, R.; Niemi, T.; Taittonen, M.; Laine, J.; Savisto, N.J.; Enerbäck, S.; et al. Functional brown adipose tissue in healthy adults. N. Engl. J. Med. 2009, 360, 1518-1525. [CrossRef] [PubMed]

109. Zingaretti, M.C.; Crosta, F.; Vitali, A.; Guerrieri, M.; Frontini, A.; Cannon, B.; Nedergaard, J.; Cinti, S. The presence of UCP1 demonstrates that metabolically active adipose tissue in the neck of adult humans truly represents brown adipose tissue. FASEB J. 2009, 23, 3113-3120. [CrossRef] [PubMed]

110. Wang, J.; Li, D.; Wang, P.; Hu, X.; Chen, F. Ginger prevents obesity through regulation of energy metabolism and activation of browning in high-fat diet-induced obese mice. J. Nutr. Biochem. 2019, 70, 105-115. [CrossRef]

111. Tung, Y.-T.; Hsu, Y.-J.; Chien, Y.-W.; Huang, C.-C.; Huang, W.-C.; Chiu, W.-C. Tea Seed Oil Prevents Obesity, Reduces Physical Fatigue, and Improves Exercise Performance in High-Fat-Diet-Induced Obese Ovariectomized Mice. Molecules 2019, 24, 980. [CrossRef]

112. Zhang, Z.; Zhang, H.; Li, B.; Meng, X.; Wang, J.; Zhang, Y.; Yao, S.; Ma, Q.; Jin, L.; Yang, J.; et al. Berberine activates thermogenesis in white and brown adipose tissue. Nat. Commun. 2014, 5, 5493. [CrossRef]

113. Song, N.-J.; Choi, S.; Rajbhandari, P.; Chang, S.-H.; Kim, S.; Vergnes, L.; Kwon, S.-M.; Yoon, J.-H.; Lee, S.-C.; $\mathrm{Ku}, \mathrm{J} . \mathrm{M}$.; et al. Prdm4 induction by the small molecule butein promotes white adipose tissue browning. Nat. Methods 2016, 12, 479-481. [CrossRef]

114. Joo, J.I.; Kim, N.H.; Choi, J.-W.; Yun, J.W. Proteomic Analysis for Antiobesity Potential of Capsaicin on White Adipose Tissue in Rats Fed with a High Fat Diet. J. Proteome Res. 2010, 9, 2977-2987. [CrossRef]

115. Choi, H.; Kim, C.-S.; Yu, R. Quercetin Upregulates Uncoupling Protein 1 in White/Brown Adipose Tissues through Sympathetic Stimulation. J. Obes. Metab. Syndr. 2018, 27, 102-109. [CrossRef] [PubMed]

116. Zhang, F.; Su, H.; Song, M.; Zheng, J.; Liu, F.; Yuan, C.; Fu, Q.; Chen, S.; Zhu, X.; Wang, L.; et al. Calcium Supplementation Alleviates High-Fat Diet-Induced Estrous Cycle Irregularity and Subfertility Associated with Concomitantly Enhanced Thermogenesis of Brown Adipose Tissue and Browning of White Adipose Tissue. J. Agric. Food Chem. 2019, 67, 7073-7081. [CrossRef] [PubMed]

117. Yin, N.; Zhang, H.; Ye, R.; Dong, M.; Lin, J.; Zhou, H.; Huang, Y.; Chen, L.; Jiang, X.; Nagaoka, K.; et al. Fluvastatin Sodium Ameliorates Obesity through Brown Fat Activation. Int. J. Mol. Sci. 2019, 20, 1622. [CrossRef] [PubMed]

118. Dewal, R.S.; Stanford, K.I. Effects of exercise on brown and beige adipocytes. Biochim. Biophys. Acta 2019, 1864, 71-78. [CrossRef]

119. Otero-Díaz, B.; Rodríguez-Flores, M.; Sánchez-Muñoz, V.; Monraz-Preciado, F.; Ordoñez-Ortega, S.; Becerril-Elias, V.; Baay-Guzmán, G.; Obando-Monge, R.; García-García, E.; Palacios-González, B.; et al. Exercise Induces White Adipose Tissue Browning Across the Weight Spectrum in Humans. Front. Physiol. 2018, 9. [CrossRef]

120. Carrière, A.; Jeanson, Y.; Berger-Müller, S.; André, M.; Chenouard, V.; Arnaud, E.; Barreau, C.; Walther, R.; Galinier, A.; Wdziekonski, B.; et al. Browning of White Adipose Cells by Intermediate Metabolites: An Adaptive Mechanism to Alleviate Redox Pressure. Diabetes 2014, 63, 3253-3265. [CrossRef]

121. Takahashi, H.; Alves, C.R.R.; Stanford, K.I.; Middelbeek, R.J.W.; Nigro, P.; Ryan, R.E.; Xue, R.; Sakaguchi, M.; Lynes, M.D.; So, K.; et al. TGF- $\beta 2$ is an exercise-induced adipokine that regulates glucose and fatty acid metabolism. Nat. Metab. 2019, 1, 291-303. [CrossRef]

122. Lee, P.; Linderman, J.D.; Smith, S.; Brychta, R.J.; Wang, J.; Idelson, C.; Perron, R.M.; Werner, C.D.; Phan, G.Q.; Kammula, U.S.; et al. Irisin and FGF21 Are Cold-Induced Endocrine Activators of Brown Fat Function in Humans. Cell Metab. 2014, 19, 302-309. [CrossRef]

123. Roberts, L.D.; Boström, P.; O’Sullivan, J.F.; Schinzel, R.T.; Lewis, G.D.; Dejam, A.; Lee, Y.-K.; Palma, M.J.; Calhoun, S.; Georgiadi, A.; et al. $\beta$-Aminoisobutyric acid induces browning of white fat and hepatic $\beta$-oxidation and is inversely correlated with cardiometabolic risk factors. Cell Metab. 2014, 19, 96-108. [CrossRef]

124. De Souza, C.J.; Hirshman, M.F.; Horton, E.S. CL-316,243, a $\beta 3$-specific adrenoceptor agonist, enhances insulin-stimulated glucose disposal in nonobese rats. Diabetes 1997, 46, 1257-1263. [CrossRef]

125. Cypess, A.M.; Weiner, L.S.; Roberts-Toler, C.; Elía, E.F.; Kessler, S.H.; Kahn, P.A.; English, J.; Chatman, K.; Trauger, S.A.; Doria, A.; et al. Activation of human brown adipose tissue by a $\beta 3$-adrenergic receptor agonist. Cell Metab. 2015, 21, 33-38. [CrossRef] [PubMed] 
126. Michel, M.C.; Korstanje, C. $\beta 3$-Adrenoceptor agonists for overactive bladder syndrome: Role of translational pharmacology in a repositioning clinical drug development project. Pharmacol. Ther. 2016, 159, 66-82. [CrossRef] [PubMed]

127. Hondares, E.; Rosell, M.; Gonzalez, F.J.; Giralt, M.; Iglesias, R.; Villarroya, F. Hepatic FGF21 expression is induced at birth via PPARalpha in response to milk intake and contributes to thermogenic activation of neonatal brown fat. Cell Metab. 2010, 11, 206-212. [CrossRef] [PubMed]

128. Hanssen, M.J.; Broeders, E.; Samms, R.J.; Vosselman, M.J.; Van Der Lans, A.A.; Cheng, C.C.; Adams, A.C.; Lichtenbelt, W.D.V.M.; Schrauwen, P. Serum FGF21 levels are associated with brown adipose tissue activity in humans. Sci. Rep. 2015, 5, 10275. [CrossRef] [PubMed]

129. Puigserver, P.; Wu, Z.; Park, C.W.; Graves, R.; Wright, M.; Spiegelman, B.M. A cold-inducible coactivator of nuclear receptors linked to adaptive thermogenesis. Cell 1998, 92, 829-839. [CrossRef]

130. Hondares, E.; Rosell, M.; Díaz-Delfín, J.; Olmos, Y.; Monsalve, M.; Iglesias, R.; Villarroya, F.; Giralt, M. Peroxisome proliferator-activated receptor $\alpha(\operatorname{PPAR} \alpha)$ induces PPAR $\gamma$ coactivator $1 \alpha(\mathrm{PGC}-1 \alpha)$ gene expression and contributes to thermogenic activation of brown fat involvement of PRDM16. J. Biol. Chem. 2011, 286, 43112-43122. [CrossRef]

131. Okla, M.; Ha, J.H.; Temel, R.E.; Chung, S. BMP7 drives human adipogenic stem cells into metabolically active beige adipocytes. Lipids 2015, 50, 111-120. [CrossRef]

132. Whittle, A.J.; Carobbio, S.; Martins, L.; Slawik, M.; Hondares, E.; Vázquez, M.J.; Morgan, N.; Csikasz, R.I.; Gallego, R.; Rodriguez-Cuenca, S.; et al. BMP8B increases brown adipose tissue thermogenesis through both central and peripheral actions. Cell 2012, 149, 871-885. [CrossRef]

133. Hoffmann, J.M.; Grünberg, J.R.; Church, C.; Elias, I.; Pálsdóttir, V.; Jansson, J.-O.; Bosch, F.; Hammarstedt, A.; Hedjazifar, S.; Smith, U. BMP4 Gene Therapy in Mature Mice Reduces BAT Activation but Protects from Obesity by Browning Subcutaneous Adipose Tissue. Cell Rep. 2017, 20, 1038-1049. [CrossRef]

134. Digby, J.E.; Montague, C.T.; Sewter, C.P.; Sanders, L.; Wilkison, W.O.; O’Rahilly, S.; Prins, J.B. Thiazolidinedione exposure increases the expression of uncoupling protein 1 in cultured human preadipocytes. Diabetes 1998, 47, 138-141. [CrossRef]

135. Fayyad, A.M.; Khan, A.A.; Abdallah, S.H.; Alomran, S.S.; Bajou, K.; Khattak, M.N.K. Rosiglitazone Enhances Browning Adipocytes in Association with MAPK and PI3-K Pathways During the Differentiation of Telomerase-Transformed Mesenchymal Stromal Cells into Adipocytes. Int. J. Mol. Sci. 2019, 20, 1618. [CrossRef] [PubMed]

136. Villarroya, F.; Vidal-Puig, A. Beyond the Sympathetic Tone: The New Brown Fat Activators. Cell Metab. 2013, 17, 638-643. [CrossRef] [PubMed]

137. Bordicchia, M.; Liu, D.; Amri, E.Z.; Ailhaud, G.; Dessì-Fulgheri, P.; Zhang, C.; Takahashi, N.; Sarzani, R.; Collins, S. Cardiac natriuretic peptides act via p38 MAPK to induce the brown fat thermogenic program in mouse and human adipocytes. J. Clin. Investig. 2012, 122, 1022-1036. [CrossRef] [PubMed]

138. Rao, R.R.; Long, J.Z.; White, J.P.; Svensson, K.J.; Lou, J.; Lokurkar, I.; Jedrychowski, M.P.; Ruas, J.L.; Wrann, C.D.; Lo, J.C.; et al. Meteorin-like is a hormone that regulates immune-adipose interactions to increase beige fat thermogenesis. Cell 2014, 157, 1279-1291. [CrossRef] [PubMed]

139. Gnad, T.; Scheibler, S.; Von Kügelgen, I.; Schéele, C.; Kilic, A.; Glöde, A.; Hoffmann, L.S.; Reverte-Salisa, L.; Horn, P.; Mutlu, S.; et al. Adenosine activates brown adipose tissue and recruits beige adipocytes via A2A receptors. Nature 2014, 516, 395-399. [CrossRef] [PubMed]

140. Hashimoto, O.; Funaba, M.; Sekiyama, K.; Doi, S.; Shindo, D.; Satoh, R.; Itoi, H.; Oiwa, H.; Morita, M.; Suzuki, C.; et al. Activin E Controls Energy Homeostasis in Both Brown and White Adipose Tissues as a Hepatokine. Cell Rep. 2018, 25, 1193-1203. [CrossRef] [PubMed]

141. Sekiyama, K.; Ushiro, Y.; Kurisaki, A.; Funaba, M.; Hashimoto, O. Activin E enhances insulin sensitivity and thermogenesis by activating brown/beige adipocytes. J. Veter. Med. Sci. 2019, 81, 646-652. [CrossRef]

142. Villarroya, F.; Cereijo, R.; Villarroya, J.; Giralt, M. Brown adipose tissue as a secretory organ. Nat. Rev. Endocrinol. 2017, 13, 26. [CrossRef]

143. Deshmukh, A.S.; Peijs, L.; Nielsen, S.; Bayarri-Olmos, R.; Larsen, T.J.; Jespersen, N.Z.; Hattel, H.; Holst, B.; Garred, P.; Tang-Christensen, M.; et al. Proteomics-based comparative mapping of the human brown and white adipocyte secretome reveals EPDR1 as a novel batokine. bioRxiv 2018, 402867. [CrossRef] 
144. Cereijo, R.; Gavaldà-Navarro, A.; Cairó, M.; Quesada-López, T.; Villarroya, J.; Morón-Ros, S.; Sánchez-Infantes, D.; Peyrou, M.; Iglesias, R.; Mampel, T.; et al. CXCL14, a Brown Adipokine that Mediates Brown-Fat-to-Macrophage Communication in Thermogenic Adaptation. Cell Metab. 2018, 28, 750-763.e6. [CrossRef]

145. Soler-Vázquez, M.C.; Mera, P.; Zagmutt, S.; Serra, D.; Herrero, L. New approaches targeting brown adipose tissue transplantation as a therapy in obesity. Biochem. Pharmacol. 2018, 155, 346-355. [CrossRef] [PubMed]

146. Alcalá, M.; Calderon-Dominguez, M.; Serra, D.; Herrero, L.; Viana, M. Mechanisms of Impaired Brown Adipose Tissue Recruitment in Obesity. Front. Physiol. 2019, 10, 94. [CrossRef] [PubMed]

147. Reitman, M.L. Of mice and men - environmental temperature, body temperature, and treatment of obesity. FEBS Lett. 2018, 592, 2098-2107. [CrossRef] [PubMed]

148. West, D.B.; Boozer, C.N.; Moody, D.L.; Atkinson, R.L. Dietary obesity in nine inbred mouse strains. Am. J. Physiol. Integr. Comp. Physiol. 1992, 262, R1025-R1032. [CrossRef]

149. Montgomery, M.K.; Hallahan, N.L.; Brown, S.H.; Liu, M.; Mitchell, T.W.; Cooney, G.J.; Turner, N. Mouse strain-dependent variation in obesity and glucose homeostasis in response to high-fat feeding. Diabetologia 2013, 56, 1129-1139. [CrossRef]

150. Kodela, E.; Moysidou, M.; Karaliota, S.; Koutmani, Y.; Tsakanikas, P.; Kodella, K.; A Karavia, E.; E Kypreos, K.; Kostomitsopoulos, N.; Karalis, K.P. Strain-specific Differences in the Effects of Lymphocytes on the Development of Insulin Resistance and Obesity in Mice. Comp. Med. 2018, 68, 15-24.

(C) 2020 by the authors. Licensee MDPI, Basel, Switzerland. This article is an open access article distributed under the terms and conditions of the Creative Commons Attribution (CC BY) license (http://creativecommons.org/licenses/by/4.0/). 